\title{
Computerization of cartographic publishing activity - an outline of the problem exemplified by the former monopolist in Poland
}

\begin{abstract}
The post-1989 transition from a centrally planned economy to a free-market economy generated new investment opportunities in Poland, heavily impacted by computerization. The article analyses the genesis, course and effects of implementation of computerization in a cartographic publishing house which spent several decades operating on a typical Central and Eastern European market. It also highlights the multi-dimensional nature of this process, presenting it in the context of political and socio-economic changes. The author indicates that the factors hindering efficient implementation of computerization were the very qualities which in the past determined the enterprise's market potential: a great reserve of source and technical materials for publishing maps, efficient technological facilities, experienced employees and the management who sought modernization, but underestimated the potential of computerization and had to deal with its own psychological barriers related to the issue.
\end{abstract}

Keywords: cartography, computerization, business management, psychological barriers, Central and Eastern Europe

\section{Introduction}

The economic system which began to take shape in Poland after 1989 brought with it a great many changes. Many of them were influenced by computerization, which introduced a new model for managing production processes and enterprises. It also affected the world of cartographic publications, in which the State Cartographical Publishing House (Polish: Państwowe Przedsiębiorstwo Wydawnictw Kartograficznych; PPWK) was a well-established leader.

PPWK's strong market position at the turn of the 1980s and 1990s was based on its monopolistic function which the socialist authorities had assigned to it in 1951, already when it was first established. Its core activity consisted in publishing general and educational cartographic publications, the latter for all educational levels, as well as professional literature. Until the early 1990 s, the company had virtually no competition. The centrally managed state used monopolization to ensure that state enterprises had stable market positions, regardless of the quality and profitability of the manufactured goods.

PPWK was organised in a manner compliant with the model applicable to all publishers of this type active in the Eastern Bloc countries. For over 40 years, their publishing processes used similar technologies and tools for map production. Management of the Eastern Bloc publishing houses was conducted on the basis of general principles adopted during international conferences of geodetic and cartographic services of the socialist countries, which meant that computerization affected them in a similar way. Virtually all of those publishing houses used the same digital tools for producing serial maps. These conditions created a fertile ground for international cooperation, but the wave of socio-political changes which swept through Eastern Europe in the last decades of the 
20th century was by no means conductive for such course of development.

The transition from a centrally planned economy to a free-market-based model has created apt conditions for the emergence of many economic entities targeting the same customer groups and generated new investment opportunities in which computerization played an important role. It entered the market with representative offices of foreign companies and private persons dreaming of rapid economic success. Free-market mechanisms favoured entrepreneurial and open-minded people whose small businesses quickly reorganised the structure of the publishing market. Former monopolists, including PPWK, had to find their footing in the so-created new economic environment.

In her analysis of the genesis, course and effects of implementation of computerization in PPWK, a cartographic publishing house with decades-long tradition, the author posed several fundamental questions, including the following - how did computerization enter the Polish cartographic business? How has it changed the publishing market? What facilitated and what hindered its introduction? How did it affect management processes and cartographic production efficiency? What kind of barriers had to be overcome by its users? Who were its supporters and opponents? How has computerization changed the map development process and the publisher's market position? Using the example of the former monopolist, which represents a typical enterprise model for the Eastern Bloc countries, the author does not try to provide exhaustive answers to the above-mentioned questions, but attempts to outline the multi-dimensional nature of the computerization process instead.

The source materials used for this analysis were the documents stored in the State Archive in Warsaw concerning the publishing house as a state-owned enterprise until 1991, as well as post-1991 documents kept in the PPWK's own archive concerning the post-privatization history of the company i.e. the period after the transformation of the state-owned enterprise into a joint-stock company (1991) and the change of its name to Polish Cartographical Publishing House (PPWK). Relevant stock market reports and prospectuses, published after PPWK became a public company (1995) were also analysed. The author carried out interviews with former employees in order to supplement the knowledge acquired from the above-listed documents.

The main research methods consisted in analysing the documents and conducting unstructured interviews with people who were employed at PPWK in the analysed period. 40 people out of nearly 200 employees were selected for the research, representing different employee groups with varying work tenures and responsibilities. Three employee groups were created on the basis of the length of employees' tenures - employees with short tenures (up to 10 years), people in pre-retirement age (5 years to the retirement age or less) and other employees. Employees of specialised departments were further divided into subgroups on the basis of the type of work they performed. The analysis covered editors (20 people), employees of auxiliary departments - drawers and bookbinders (10 people) - and members of the managerial staff (10 people).

\section{Determinants of map production before 1989}

As the economy of the Polish People's Republic (1952-1989) was centrally managed, the map publishing house had to consult each decision with the state authorities responsible for central planning. Its management had to cooperate with military and civilian preventive censorship at every stage of the publishing process. Once the final version of the publication was approved by the censorship, the publisher had to set the price and circulation in cooperation with other relevant central authorities. The entire decision-making process included many people representing various control bodies of the state and the enterprise itself (B. Konopska 2013).

\subsection{Internal controls and censorship}

The scope of internal controls was defined by the procedure implemented in 1963, while the results of said controls took the shape of post-inspection reports which contained comprehensive overviews of all the work conducted in the course of the development, technical preparation and printing of individual publications. The inspector was first required to summarise 
and evaluate the work of a proofreader, then to describe "their own inspection" and assess the level of compliance between the work performed and the editorial and technical assumptions. The inspector was also the one who decided how the revealed issues should be resolved and whether the map should be moved to the further stage of production. The next item in the report was "verification of the circulation", which was meant to confirm that the number of actual printed copies complies with the amount set by the censorship authorities. At least ten people from various departments of the enterprise had to sign the proof of the map. The director added his signature before the copies were sent for distribution.

The design of the above protocol reflected the control points in the process of development, reproduction and printing of maps. The outlined procedure, with just minor modifications, remained in force until the early 1980s, i.e. the end of preventive censorship. Still, such behavioural patterns lasted much longer in the mentality of the employees responsible for these controls, because, despite the complete liquidation of the censorship office in May 1990, its place in the structure of the publishing house remained unchanged.

\subsection{Business economy}

The time and cost required for bringing a map to the market were of little importance. The publication's retail price was only loosely related to the financial outlays incurred in its production. The state publisher did not have to care about the profitability of individual titles, because there was no pressure for it to make profit. The use of effective economic methods was not possible because, as explained by J. Kaliński (2013, pp. 53-57), the planning process did not take into consideration the economic calculation focused on profit maximisation at the scale of the entire enterprise. Economic categories such as prices, wages, interest rates and profit were referred to in implementation of the production and consumption plan, but they were meant to perform informative and motivational functions only. What counted most was the economic calculation conducted at the level of the entire society, as part of actions of a centralised and bureaucratic planning apparatus (A. Wakar 1965, after J. Kaliński 2013).
As noted by W. Morawski (2013), the main premise of socialism was the belief that political decisions could be used to develop a system that could satisfy social needs and remained insusceptible to overproduction-related crises. As a result, at the enterprise level, there was a strong belief that the decisions taken at a higher level were correct and that the producer's role was more important than that of consumer's. In fact, the high circulation levels of titles expected by consumers paradoxically did not meet their needs. Mainly because of an inefficient, centrally managed distribution system.

\subsection{Human capital}

The operation of PPWK was fully dependent on decisions of the authorities from the very beginning. The management consisted of people who pledged their loyalty to the authorities, while the personnel was built gradually, mainly from people who were educated after World War II. In September 1952, the company conducted its first courses for editorial staff (50 hours) and cartographic drawers (30 hours) ${ }^{1}$. It is worth nothing that from the very beginning, the publishing house not only worked on improving the editing skills of the editors, but also implemented innovative reproduction technologies and built its own geographic information database.

It also had a strong basis for further development in the transformation period - knowledge, practical skills and an experienced editorial team with a high level of stability and the length of the average tenure ${ }^{2}$, not to mention specialization within a single industry. The drawbacks were linked to the belief that the decisions made by the monopolist were infallible, which led to ignoring the rules of operation under free market conditions.

\section{Computerization of production and management processes}

The post-1989 growth of the new economic system leading towards establishment of a free

\footnotetext{
${ }^{1}$ Archiwum Akt Nowych (Archive of New Records), fonds 1091 , ref. no. $1 / 8$, K. 52

2 A stability index is the ratio of the number of employees working at the organization in a given year to the number of employees of the organization in the previous year. The average tenure means the average length of employment in a given job in a given organizational unit.
} 
market economy in Poland resulted in gradual elimination of all elements of the centralised control over publishing houses and created a statutory ground for the development of entrepreneurship, guaranteeing unlimited access to paper, printing services, as well as imports of modern technology and geographical information. The Act on Freedom of Economic Activities ("Dziennik Ustaw" [Journal of Laws] 1988, No. 41, item 324) made it possible for different business entities to enter the cartographic market.

\subsection{Privatization of enterprises}

After 1989, Poland was a state which was politically unstable, but conducive to economic changes. It guaranteed the freedom to conduct manufacturing operations, did not institutionally limit the import of printing technologies and services, and encouraged state enterprises, including PPWK, to privatize. Ultimately, a jointstock company was established which received the right to use the assets of the liquidated PPWK against payment for ten years, pursuant to the Act of 13 July 1990 on Privatization of State-owned Enterprises. After paying $42 \%$ of the amount due, the terms of the agreement were changed to grant the joint-stock company full ownership of all property of the former state-owned enterprise. On 1 January 1992, PPWK began to operate as a joint-stock company. Five years later, it was first listed on the Warsaw Stock Exchange. The company's founders were 233 natural persons, including almost all of its employees (Prospekt emisyjny [Prospectus] 2007).

\subsection{Competition and publishing boom}

There were many companies founded at the turn of the 1980s and 1990s that sold books, magazines, and maps. New business entities quickly entered the "dormant" publishing industry, which caused a real publishing boom in Poland. The unravelling system of central control of publishing houses was quickly disappearing, and a free market emerged, making it possible for anyone interested to take a risk and start a business.

Compared to new book-oriented publishing houses, companies which intended to publish maps operated more calmly. It was most likely motivated by the specific nature of the carto- graphic product, more capital-intensive and still traditional production technology, and the relatively weak market for printing services. At that time, there were around 150 registered companies which identified themselves as cartographic publishers or mentioned publishing maps in their activities (J. Krupski, R. Janusiewicz 2000). There were also some attempts to launch foreign publishers on the Polish market, but none of the Western tycoons with potential that could threaten PPWK's market position decided to come to Poland.

Still, the publishers established in the early 1990s permanently changed the market environment in which PPWK operated. Most of these 150 new enterprises, usually regional in scope, had limited offers of a few titles only, but taken together, these publishing houses slowly began to threaten the position of PPWK which still operated as if it was a monopolist. New publishers of maps and atlases were underestimated by the privatized, and thus heavily capitalised, PPWK, even though they outperformed it from the beginning with their flexible market reactions, low production costs, low and sometimes even undercut prices of the final products, and unconventional forms of distribution. Sometimes, their products violated the principles of fair competition and constituted breaches of PPWK's copyright ${ }^{3}$.

\subsection{Social climate}

As noted by S. Kamosiński (2012, p. 264), the success of political and economic reforms was largely impacted by the atmosphere of irreversibility that permeated Poland: "Poles believed that there was no return to socialism after 1989 and thus adapted faster to the new economic conditions and the new economic reality". Quoting L. Balcerowicz and A. Rzońca (2010, p. 56), S. Kamosiński wrote also that in spite of the homo sovieticus phenomenon, the above-mentioned atmosphere was the reason why "the scale and speed of people's adaptation to the new conditions was so amazing."

The increase in wealth and post-modernity have paved the way for new ways of spending free time. Mass forms of recreation organised by the state authorities disappeared along with

\footnotetext{
${ }^{3}$ https://archiwum.rp.pl/artykul/429068.html
} 
the socialist system. They were replaced by self-organised, active, but rather short holidays, which meant a greater demand for cartographic products with fairly uncomplicated content, mainly for regions with high sightseeing values. The new publishers carefully observed the mechanics of operation of foreign markets, from which they imported technologies for the production of maps, and trusting their intuition, flooded the cartographic publications market with fairly simple maps.

The financially strong PPWK ignored the changes taking place in the society's mentality and the modes of spending free time and continued to offer products which still represented high quality, but did not meet people's expectations. The company's previous advantages - experience in the traditional map development technology and access to the analogue materials for their production (diapositives) worth several million - have become hindrances on the way to computerisation. It can be summarised that the company's powerful resources had a negative impact on its management decisions, which ultimately affected the company's economic results and gave rise to silent conflicts between employees.

PPWK's declining market share and its inability to successfully implement computerisation resulted in financial shareholders taking over the control of the company. Unencumbered by the company's past, they were able to make clear decisions. In the face of a noticeable decrease of the market share, PPWK decided to commission the first professional cartographic market analysis in Poland. It was carried out in the second half of 2000 by the Public Opinion Research Centre (CBOS). It was made up of two series of studies. The first series concerned the characteristics of the publishing market and defining PPWK's position in said market. The second series focused on the cartographic product and its user, defining the socio-demographic characteristics of map users, their impressions of the products in question, the ways in which they use the maps, and the hierarchy of importance of maps' features (J. Sas-Uhrynowski 2001, B. Konopska 2005).

\subsection{Globalization}

The emergence of so many new cartographic enterprises with a growing publishing offer in just a few years was not only the result of economic changes, but also a side-effect of globalization of production of IT equipment. When Poland was evolving into a market economy, the world of cartography was undergoing a technological revolution concerning the manner of developing and printing maps. Departments specialising in the traditional technology, employing large editorial teams divided into substantive and technical specialists, began to disappear from the organizational structures of cartographic publishing houses. These technological changes reached Poland in the last decade of the 20th century. Paradoxically, the newly established often unfounded companies became the pioneers in introducing modern technology for map development, not the former monopolist with the greatest financial capabilities. Small publishing houses were the first to organise their entire production processes solely on the basis of information technologies.

The so-called traditional technology constituted an almost insurmountable barrier for many companies, as it required investing a lot of capital in map production tools and housing facilities for their installation, and employing many specialists. Digital map development technology allowed many companies who could not afford such investments to enter the cartography market. Unlike traditional technology, information technology was more easily available and much less capital intensive. Continuous improvement of the process facilitated the efficient development of maps on the basis of relatively low financial outlays compared to similar works conducted with the help of the traditional technology.

\subsection{Psychological barriers}

As already mentioned, the analysis of the specific case of the former cartographic monopolist revealed that its strengths from the era of the centrally managed economy became its weaknesses under free market conditions. The above-mentioned great reserves of materials for production of map in the traditional technology, accumulated over forty years, became an obstacle to further development. The same could be said about PPWK's competent and experienced staff that felt personally threatened by computerization. The professional ex- 
perience of the staff was closely related to its demographic structure.

A large percentage of people employed in PPWK had many years of work experience or were in the pre-retirement age. The management staff, which as the executives in charge of the state publishing house carried out the privatization process and started modernizing the enterprise, also represented employees with longer work tenures. When they become members of the management board heading a joint-stock company, they were mentally unable to meet the next modernization challenges and facilitate the digitalization of the publishing house's production processes and computerization of its management processes. Such decisions would have to result in liquidation of those departments which were closely related to the traditional technology, and thus in a dismissal of many employees, including some of the staff working in administrative departments. The fact that the new members of the management board were the same age as the employees working with the traditional technology and tended to identify with this group, only worsened the problem. Despite the needs of the company whose market position was clearly at risk, PPWK entered a several-years-long period of evolutionary development marked by indecisive changes, half measures and only surface-level computerization.

\subsection{Evolutionary approach to implementing changes}

The introduction of computerization in PPWK began in the early 1990s with the modernization of phototypesetting (Prospekt emisyjny 1994). The issue of series $C$ shares was announced in 1996 and $30 \%$ of the so-obtained funds were meant to be spent on modernization of the technological line and training employees. At that time, PPWK bought digital but incomplete technological lines, hired the first batch of specialists and trained selected employees in the digital map development technology. The other employees were still threatened by the upcoming changes and were in no way prepared to face them. Consequently, they were fully aware that their competences were no longer useful and inevitably began to fear for their jobs. The management board lacked the courage to make unambiguous, but unpopular decisions concerning technological changes, because it would result in redundancies. The board members' previous experience - acquired in a state-owned company whose leadership position was unquestioned - made them accustomed to hidden unemployment and simulated tasks, and resulted in creation of psychological barriers which they were unable to overcome, despite the expectations of shareholders.

The changes introduced under such circumstances led to growing investment outlays related to the purchase of expensive technology, but did not result in reducing the production costs, increasing the profitability of the produced maps, and the growth of profits, in which the investors were naturally interested. The financial statements provided the investors with promising news concerning implementation of computerization, but did not mention that introduction of said changes was slowed down administratively. For example, when the digital technology was used to create maps, only linear map elements were developed digitally, while all other elements were prepared using the traditional method. It was meant to prolong the existence of the departments indicated for later liquidation - the ones responsible for preparing fair copies of maps and reproductions. The employees that specialised in the traditional technology perceived computerization efforts as unnecessary costs, because at that time the old techniques were the only methods which they associated with professionalism. Computerization became a source of internal "silent" conflict.

The resistance was also reinforced by the fact that many researchers and academics did not have the best opinion on computerization of map development processes, including university-based cartographers who often had no access to modern technologies, as the universities were heavily under-invested at that point, and thus ignored their possibilities and did not educate students on this topic. This group had initially significant impact on PPWK, because many years of close cooperation with universities created strong links between the institutions and their employees. Innovation was brought to technical universities by Intergaph, but this company's offering was initially treated simply as a technology for creating geodetic surveys. Nevertheless, the experience of technical uni- 
versities played an important role in further development of PPWK, as the graduates of these institutions went on to become leaders of digital technologies at this very company. Their experience in map editing was small, but they were mentally prepared to work in an IT environment.

\subsection{Tough market rules}

Meanwhile, small publishing houses used digital technologies to flood local markets with maps, pushing PPWK products out. Convinced of its own professionalism, the management board of PPWK did not believe that it was possible for it to lose its market leader position in Poland, and tended to perceive all the issues as just temporary disturbances caused by internal difficulties. What is more, the board was slow in introduction of changes in the organizational culture, only half-satisfying the ambitions of the company's strategic investors and younger employees who awaited changes.

It can be stated that, all in all, the first approach to computerization of PPWK, i.e. an attempt to introduce changes in its organizational culture in an evolutionary manner, ended in failure. The actual changes were not introduced until August 1999, after a hostile takeover (i.e. inconsistent with the intentions of the management) of the publishing house by financial investors who grew impatient with the lack of effects of computerisation (i.e. profit for them). The production process was computerized, and an IT system for company management was introduced.

The new management board, unencumbered by psychological barriers and relations with the employees, introduced changes in the organizational culture in a revolutionary way, i.e. quickly and radically, taking a clear stance. Everything that was associated with the old technology was deemed to represent ineffective obsolescence. The new management board closed the departments related to the traditional map development technology and made unpopular decisions regarding collective redundancies. It introduced the project-based management system already used for production of maps across the globe, as well as a matrix structure. Finally, it implemented changes in non-technical departments (administration, accounting, logistics, distribution), introducing an IT system for managing the information flow.

\section{Conclusions}

The computerization of production and management processes at PPWK was conducted in a very different manner than in the new cartographic publishing houses created after 1989. The factors hindering efficient implementation of computerization at PPWK were paradoxically the very qualities which in the past determined the enterprise's market potential - a great reserve of sources and technical materials for issuing maps, efficient, albeit capital-intensive technological facilities, experienced employees, and management who sought modernization, but had no experience in operating under free market conditions, underestimated the potential of computerization and had to deal with their own psychological barriers related to this issue.

Changing the mind-sets of the employees and the management board required much more time than it took to purchase relevant hardware and software, which is why implementation of the new, computerized organization of work took so long. PPWK's permanent loss of its market share, despite the fact that it maintained its leadership position, provided evidence of the economic inefficiency of using the traditional methods to produce maps. In the final stage of the computerization of processes, which was achieved circa 2002, the length of the production cycle for the major titles was shortened from $1-3$ years to $6-8$ months, with a $20-30 \%$ reduction in the cost of editorial work and a simultaneous increase in the salaries of most specialised employees (B. Konopska 2001). Dissemination of advanced information technologies introduced a different way of thinking about the development and usage of maps. Collecting cartographic data in the form of digital databases made it possible to quickly access said data.

Although the above-presented considerations constitute a case study, the described experiences related to effects of computerization on the production, management and the mind-sets of employees may become helpful in further research on the implementation of computerization in other publishing houses. They may also be useful in the context of similar analyses conducted in other former Warsaw Pact countries, and in the study of history of cartographic publishing houses that thrived on the European market during global technological changes. 


\section{Literature}

Balcerowicz L., Rzońca A., 2010, Systemy instytucjonalne a siły napędowe gospodarki. In: Zagadki wzrostu gospodarczego. Sity napędowe i kryzysy - analiza porównawcza, eds. L. Balcerowicz, A. Rzońca. Warszawa.

Kaliński J., 2013, Model gospodarki centralnie kierowanej w Polsce w ujęciu "szkoły wakarowskiej”. In: $W$ poszukiwaniu modelu gospodarki centralnie kierowanej, ed. P. Jachowicz. Warszawa: Oficyna Wydawnicza Szkoły Głównej Handlowej, pp. 51-62.

Kamosiński S., 2012, Losy wielkich przedsiębiorstw doby PRL w regionie kujawsko-pomorskim w okresie transformacji systemowej i po jej zakończeniu. In: Z dziejów przemysłu po 1945 roku, eds. E. Kościk, R. Kementowski. Wrocław, pp. 263-285.

Konopska B., 2001, Przeszłość i dzień dzisiejszy Polskiego Przedsiębiorstwa Wydawnictw Kartograficznych im. E. Romera SA. "Polski Przegląd Kartograficzny" T. 33, nr 3, pp.187-201.

Konopska B., 2005, Potencjalna i rzeczywista rola kartografii użytkowej na przykładzie map samochodowych i turystycznych. In: Społeczna i edukacyjna rola kartografii w Polsce, eds. J. Ostrowski, J. Pasławski, "Materiały Ogólnopolskich Konferencji Kartograficznych" T. 26, pp. 55-63.

Konopska B., 2012, Wpływ aparatu władzy w latach 1944-1989 na polskie publikacje kartograficzne do użytku powszechnego, "Instytut Geodezji i Kartografii. Seria Monograficzna" Nr 16, Warszawa.

Konopska B., 2013, The tightening of censorship rules in cartography in Poland 1944-1989, "Geoinformation Issues" Vol. 5, no. 1(5), pp. 5-20.

Krupski J., Janusiewicz R., 2000, Kartograficzny ruch i rynek wydawniczy w Polsce w latach 1989-2000. In: Kartografia polska u progu XXI wieku, eds. I. Krauze-Tomczyk, J. Pasławski, "Materiały Ogólnopolskich Konferencji kartograficznych" T. 22, Warszawa, pp. 209-242.

Morawski W., 2013, Tendencje autarkiczne w gospodarce socjalistycznej. In: W poszukiwaniu modelu gospodarki centralnie kierowanej, ed. P. Jachowicz. Warszawa: Oficyna Wydawn. Szkoły Głównej Handlowej, pp. 75-106.

Prospekt emisyjny, 1994, Warszawa: PPWK.

Prospekt emisyjny, 1996, Warszawa: PPWK.

Prospekt emisyjny, 2007, Warszawa: PPWK.

Sas-Uhrynowski J., 2001, Copernicus - PPWK wnowej szacie. "Polski Przegląd Kartograficzny" T. 33, nr 3, pp. 242-243.

Sprawozdanie Zarządu PPWK S.A. I pótrocze 2000 r. In: Prospekt emisyjny akcji, PPWK, Warszawa 2001, p. 98.

Wakar A., 1965, Ekonomia socjalizmu: wybrane zagadnienia. Warszawa: SGPiS. 